\title{
Interaction Effect of Vitamin E-selenium Supplementation and Metabolic Energy on Reproductive Performance of Joper Breeders
}

\author{
Haryuni $\mathrm{N}^{1}$, Hartutik ${ }^{2}$, Widodo $\mathrm{E}^{2}$, Wahjuningsih $\mathrm{S}^{2}$ \\ 'Department of Animal Husbandry, Nahdlatul Ulama Blitar University, East Java, Indonesia \\ ${ }^{2}$ Department of Animal Science, Brawijaya University, Malang, East Java, Indonesia \\ E-mail: eko.widodo@ub.ac.id
}

(received 26-07-2021; revised 17-10-2021; accepted 18-10-2021)

\begin{abstract}
ABSTRAK
Haryuni N, Hartutik, Widodo E, Wahjuningsih S. 2021. Pengaruh interaksi suplementasi vitamin e-selenium dan energi metabolis terhadap performa reproduksi induk Joper. JITV 26(3): 124-131. DOI: http://dx.doi.org/10.14334/jitv.v26i3.2842.

Efek samping dari oksidasi asam lemak saat sintesis lippoprotein adalah pelepasan oksigen dalam jaringan yang disebut reactive oxygen species (ROS). Stress metabolik pada indukan Joper akibat ketidak seimbangan antara ROS dan antioksidan menyebabkan penuruan produksi dan kualitas telur tetas. Oleh sebab itu perlu penelitian untuk meningkatkan performa reproduksi induk Joper dengan mengkombinasikan suplementasi vitamin E-selenium dan energi metabolik. Penelitian ini menggunakan 200 butir telur tetas hasil persilanngan antara pejantan Sentul umur 60 minggu dengan ayam petelur strain ISA BROWN umur 35 minggu yang diberi pakan perlakuan. Penelitian ini menggunakan Rancangan Acak Lengkap (RAL) Faktorial (2X4). Faktor pertama adalah level energi ( 2700 dan $2800 \mathrm{kcal} / \mathrm{kg}$ ) dan faktor kedua dosis suplementasi vitamin E-selenium (0, 25, 50, 75 dan 100ppm). Dosis selenium $1 \mathrm{ppm} / \mathrm{mg}$ vitamin E. Interaksi antara suplementasi vitamin E-selenium dan energi berpengaruh sangat nyata $(\mathrm{P}<0.01)$ dalam meningkatkan bobot DOC. Faktor tunggal level energi dan suplementasi vitamin Eselenium berpengaruh nyata $(\mathrm{p}<0.05)$ dalam menurunkan mortalitas embrio dan meningkatkan daya tetas, sedangkan fertilitas dan kualitas cangkang telur tidak dipengaruhi oleh kedua faktor perlakuan. Kesimpulan dari penelitian ini adalah interaksi antara suplementasi vitamin E-selenium dan level energi dapat meningkatkan bobot DOC Joper, sedangkan faktor tunggal suplementasi vitamin E-selenium dan level energi dapat menurunkan mortalitas embrio dan meningkatkan daya tetas. Interaksi terbaik pada supelemntasi 100 ppm vitaminE-selenium dan energi $2800 \mathrm{kcal} / \mathrm{kg}$.
\end{abstract}

Kata Kunci: Feed suplement, lippoprotein dan indukan Joper

\section{ABSTRACT}

Haryuni N, Hartutik, Widodo E, Wahjuningsih S. 2021. Interaction effect of vitamin e-selenium supplementation and metabolic energy on reproductive performance of Joper Breeders. JITV 26(3): 124-131. DOI: http://dx.doi.org/10.14334/jitv.v26i3.2842.

The side effect of fatty acid oxidation during lippoprotein synthesis is the release of oxygen in the tissue called reactive oxygen species (ROS). Metabolic stress in Joper brooders due to an imbalance between ROS and antioxidants causes a decrease in hatching egg production and quality. Therefore, research is needed to improve the reproductive performance of Joper broodstock by combining vitamin E-selenium supplementation and metabolic energy. This study used 200 hatched eggs resulting from a cross between 60 weeks old Sentul males and 35 weeks old ISA BROWN laying hens that had been treated. This study used a Factorial Completely Randomized Design (CRD) (2 x 4). The first factor is the energy level (2700 and 2800 $\mathrm{kcal} / \mathrm{kg}$ ) and the second factor is the dose of vitamin E-selenium supplementation (0, 25, 50, 75 and $100 \mathrm{ppm})$. Selenium dosage is $1 \mathrm{ppm} / \mathrm{mg}$ vitamin E. The interaction between vitamin E-selenium supplementation and energy had a very significant effect $(\mathrm{P}<0.01)$ in increasing DOC weight. The single factor energy level and vitamin E-selenium supplementation significantly $(\mathrm{p}<0.05)$ in reducing embryo mortality and increasing hatchability, while fertility and eggshell quality were not affected by the two treatment factors. The conclusion of this study is the interaction between vitamin E-selenium supplementation and energy levels can increase the weight of Joper's DOC, while the single factor of vitamin E-selenium supplementation and energy levels can reduce embryo mortality and increase hatchability. The best interaction with $100 \mathrm{ppm}$ vitamin E-selenium supplementation and energy $2800 \mathrm{kcal} / \mathrm{kg}$.

Key Words: Feed supplements, lipoprotein and Joper breeders

\section{INTRODUCTION}

The imbalance between demand and supply of native chicken meat in Indonesia is a great opportunity for the development of the native chicken business. In 2019 the demand for native chicken meat was only supplied by 30\% (Immawan et al. 2019). Joper (Jowocross) is a crossbreed between domesticated males and laying hens (Muharlien et al. 2020). The main priority in the development of the Joper hatchery industry is improving the quality of hatching eggs. Lipoprotein is one of the key factors in assessing the quality of 
hatching eggs because it is the main source of nutrition for embryonic development (Ren et al. 2021; Wang et al. 2021).

Reactive oxygen species (ROS) is one of the triggers for metabolic stress which has a major impact on immunity and regulation of body metabolism. ROS is a by-product of fatty acid oxidation in lippoprotein synthesis (Amevor et al. 2021; Zuidhof et al. 2017). To produce good quality hatching eggs, it is necessary to control the triggers of metabolic stress in breeders. Vitamin E-selenium supplementation and increased metabolic energy are solutions to control metabolic stressors in Joper breeders

Vitamin $\mathrm{E}$ is a natural antioxidant that can protect tissues from damage caused by ROS. Amevor et al. (2021) reported that selenium plays an important role in various metabolic processes in the body. Vitamin $\mathrm{E}$ works synergistically with selenium in lipid peROSidation (Abd El-Hack et al. 2017; Çelebi 2019). Metabolic energy (ME) is used for maintenance (basal metabolism, regulation of body temperature, immune response and activity, growth and egg production (Hadinia et al. 2019). Surplus energy in the body is stored as body fat mass. Body fat mass plays a role in regulating sexual maturity, egg production, egg yolk composition, maximizing the absorption of vitamin $\mathrm{E}$ and reproductive hormone precursors (Heijmans et al. 2021; Ren et al. 2021). Research is needed to determine the interaction between $\mathrm{ME}$ and the right dose of vitamin E-selenium supplementation in improving hatching egg quality because there is very little information available..

\section{MATERIALS AND METHODS}

\section{Place and time}

This research was conducted in February 2020. The research location is in the hatchery of Mr. Manto which is located in Rejotangan Village, Tulung Agung Regency, East Java Province, Indonesia.

\section{Artificial insemination}

In this study, artificial insemination was performed intravaginally by inserting semen into the cloaca of the Joper breeder as deep as 3-4 cm. This insemination was applied every 4 days at $4 \mathrm{pm}$. Semen is collected by massaging the area around the abdomen to the cloaca and collected with a graduated tube to measure its volume. Semen dilution using $0.9 \% \mathrm{NaCl}$ with the ratio between semen and $0.9 \% \mathrm{NaCl}$ is $1: 10$. The dose of inseminated semen is $0.2 \mathrm{ml} / \mathrm{hens}$. The concentration of spermatozoa used for artificial insemination refers to the results of the research by Saleh et al. (2019) of 100 million spermatozoa/hens.

\section{Hatchery management}

The incubator was cleaned by wiping the inner and outer surfaces of the incubator using a disinfectant and allowed to dry and continued with fumigation. The fumigation of the incubator was carried out by evaporating formalin into a container containing $\mathrm{KMnO}_{4}$. Evaporation is done by pouring formalin $40 \%$ in a container containing $\mathrm{KMnO}_{4}$ then the hatching machine is immediately closed and allowed to stand for $24-48$ hours with the heating condition still on. The fumigation dose per $1 \mathrm{~m}^{3}$ of hatchery area is $12-15 \mathrm{ml}$ of $40 \%$ formalin and $6 \mathrm{~g}$ of $\mathrm{KMnO}_{4}$. Handling hatching eggs before being put into the semi-authomatic incubator is cleaned by wiping the dirt on the egg shell. Temperature and humidity settings are regulated according to the needs of the embryonic development period. Day 1 to 18 the temperature is set at $37.5{ }^{\circ} \mathrm{C}$ and humidity ranges from $50-60 \%$ and on day 19 until hatching the temperature is lowered to $32-33{ }^{0} \mathrm{C}$. On day 20 until hatching humidity is set at $80 \%$. Turning eggs every 1 hour so that in a day there are 24 rounds with a slope of $45^{\circ}$ (Rahardja et al. 2020). Embryo development was observed every 7 days by candling on the 7th and 14th days after the eggs entered the semiautomatic incubator. Candling is a method used to observe the development of the embryo inside the egg by observing using light.

\section{Breeder Joper and diets}

This research is a series of studies from several studies. In previous studies, studies have been carried out on Sentul males to get the best male age which produces good quality semen for artificial insemination where the results of this study are applied to this study. The Joper broodstock used in this study were 400 hens from the ISA BROWN strain and were 35 weeks old with body weight ranging from $1.80-1.85 \mathrm{~kg}$ and in good health. These brooders were placed in individual cages with a size of $50 \times 40 \mathrm{~cm}$ and a height of $37 \mathrm{~cm}$ at the front and $30 \mathrm{~cm}$ at the back. The hatching eggs of 400 hens were collected and selected, then 200 eggs were taken to be incubated and observed and 200 eggs were used to observe the exterior quality of hatching eggs (egg shell weight and thickness). The total males used were 15 Sentul males aged 60 weeks with body weight ranging from $2.18-2.23 \mathrm{~kg}$ and in good health. Sentul roosters are placed separately from the broodstock. These males were placed in individual cages measuring $70 \times 50 \times 100 \mathrm{~cm}$. Sentul rooster was given control feed (E1V0) while Joper broodstock was given treatment feed with the addition of metabolic energy and vitamin E-selenium supplementation according to the treatment. The treatment feed was given $40 \%$ at 6 am and $60 \%$ at 2 pm. Sentul males and Joper breeders are given drinking water ad libitum. 
Table 1. The composition of the experimental feed

\begin{tabular}{|c|c|c|c|c|c|c|c|c|c|c|}
\hline \multirow{2}{*}{ Ingredients } & \multicolumn{10}{|c|}{ Experimental feed } \\
\hline & E1V0 & E1V1 & E1V2 & E1V3 & E1V4 & E2V0 & E2V1 & E2V2 & E2V3 & E2V4 \\
\hline Corn $(\%)$ & 48.90 & 48.90 & 48.90 & 48.90 & 48.90 & 51.30 & 51.30 & 51.30 & 51.30 & 51.30 \\
\hline Soy bean meal (\%) & 21.60 & 21.60 & 21.60 & 21.60 & 21.60 & 22.10 & 22.10 & 22.10 & 22.10 & 22.10 \\
\hline Rice bran $(\%)$ & 12.20 & 12.20 & 12.20 & 12.20 & 12.20 & 12.20 & 12.20 & 12.20 & 12.20 & 12.20 \\
\hline Meat bone meal (\%) & 8.00 & 8.00 & 8.00 & 8.00 & 8.00 & 8.40 & 8.40 & 8.40 & 8.40 & 8.40 \\
\hline Grit (\%) & 5.00 & 5.00 & 5.00 & 5.00 & 5.00 & 5.00 & 5.00 & 5.00 & 5.00 & 5.00 \\
\hline Limestone (\%) & 3.30 & 3.30 & 3.30 & 3.30 & 3.30 & 3.10 & 3.10 & 3.10 & 3.10 & 3.10 \\
\hline Fat powder $(\%)$ & 0.00 & 0.00 & 0.00 & 0.00 & 0.00 & 1.11 & 1.11 & 1.11 & 1.11 & 1.11 \\
\hline Complete premix (\%) & 0.50 & 0.50 & 0.50 & 0.50 & 0.50 & 0.50 & 0.50 & 0.50 & 0.50 & 0.50 \\
\hline $\begin{array}{l}\text { Monocalcium } \\
\text { phospate }(\%)\end{array}$ & 0.30 & 0.30 & 0.30 & 0.30 & 0.30 & 0.30 & 0.30 & 0.30 & 0.30 & 0.30 \\
\hline Salt $(\%)$ & 0.10 & 0.10 & 0.10 & 0.10 & 0.10 & 0.10 & 0.10 & 0.10 & 0.10 & 0.10 \\
\hline Sodium bicarbonat (\%) & 0.07 & 0.07 & 0.07 & 0.07 & 0.07 & 0.07 & 0.07 & 0.07 & 0.07 & 0.07 \\
\hline Vitamin E-selenium(ppm) & 0 & 25 & 50 & 75 & 100 & 0 & 25 & 50 & 75 & 100 \\
\hline
\end{tabular}

Calculation of feed composition using Brill Formulation software

Table 2. The nutritional content of the experimental feed

\begin{tabular}{|c|c|c|c|c|c|c|c|c|c|c|}
\hline \multirow{2}{*}{ Nutrients } & \multicolumn{10}{|c|}{ Nutritional content } \\
\hline & E1V0 & E1V1 & E1V2 & E1V3 & E1V4 & E2V0 & E2V1 & $\mathrm{E} 2 \mathrm{~V} 2$ & E2V3 & $\mathrm{E} 2 \mathrm{~V} 4$ \\
\hline $\mathrm{ME}(\mathrm{kcal} / \mathrm{kg})$ & 2,701 & 2,701 & 2,701 & 2,701 & 2,701 & 2,800 & 2,800 & 2,800 & 2,800 & 2,800 \\
\hline Crude protein $(\%)$ & 19.00 & 19.00 & 19.00 & 19.00 & 19.00 & 19.00 & 19.00 & 19.00 & 19.00 & 19.00 \\
\hline Crude fat $(\%)$ & 4.40 & 4.40 & 4.40 & 4.40 & 4.40 & 5.06 & 5.06 & 5.06 & 5.06 & 5.06 \\
\hline Crude fiber (\%) & 3.60 & 3.60 & 3.60 & 3.60 & 3.60 & 3.24 & 3.24 & 3.24 & 3.24 & 3.24 \\
\hline Lysine (\%) & 0.96 & 0.96 & 0.96 & 0.96 & 0.96 & 0.96 & 0.96 & 0.96 & 0.96 & 0.96 \\
\hline Metionin (\%) & 0.50 & 0.50 & 0.50 & 0.50 & 0.50 & 0.50 & 0.50 & 0.50 & 0.50 & 0.50 \\
\hline $\begin{array}{l}\text { Methionine + cystine } \\
(\%)\end{array}$ & 0.87 & 0.87 & 0.87 & 0.87 & 0.87 & 0.87 & 0.87 & 0.87 & 0.87 & 0.87 \\
\hline Threonine $(\%)$ & 0.75 & 0.75 & 0.75 & 0.75 & 0.75 & 0.75 & 0.75 & 0.75 & 0.75 & 0.75 \\
\hline Triptopane (\%) & 0.22 & 0.22 & 0.22 & 0.22 & 0.22 & 0.22 & 0.22 & 0.22 & 0.22 & 0.22 \\
\hline Calsium (\%) & 3.99 & 3.99 & 3.99 & 3.99 & 3.99 & 3.91 & 3.91 & 3.91 & 3.91 & 3.91 \\
\hline Total phosphorus (\%) & 0.83 & 0.83 & 0.83 & 0.83 & 0.83 & 0.78 & 0.78 & 0.78 & 0.78 & 0.78 \\
\hline Phospor avail (\%) & 0.50 & 0.50 & 0.50 & 0.50 & 0.50 & 0.49 & 0.49 & 0.49 & 0.49 & 0.49 \\
\hline Sodium $(\%)$ & 0.13 & 0.13 & 0.13 & 0.13 & 0.13 & 0.13 & 0.13 & 0.13 & 0.13 & 0.13 \\
\hline
\end{tabular}

Calculation of feed composition using Brill Formulation software

$\mathrm{ME}=$ Metabolism energy

\section{Parameters measure}

The measurement process in a research is very essential because that is where the numbers are obtained to be processed and analyzed so that the answers to the questions in the research are obtained. The procedure used to obtain data based on the variables observed in this study was as follows:

\section{Egg weight, Egg shell weight (ESW) and Egg shell thickness (EST)}

Egg weight (EW) was measured by weighing the hatching eggs. Egg weight measurement was carried out every day and then the average was taken for each week. The weight of the egg shell is one of the determinants of egg quality, especially for hatching eggs. A small eggshell weight indicates a thin eggshell and is not good at hatching. The egg shell weight was measured by breaking the egg and removing the egg white and yolk. Then the weight of the shell was weighed and the results were recorded.The thickness of the egg shell is one of the determinants of the quality of hatching eggs. The thickness of the egg shell is closely related to the ability to hatch. The thickness of the eggshell was measured by breaking the egg, removing the white and yolk and then measuring the thickness of the egg shell using a caliper. 


\section{Fertility}

Measurement of fertility by calculating the percentage of fertile eggs based on the number of eggs that enter the incubator. Percentage of mortality were calculated based on fertile eggs.

$$
\text { Fertility }(\%)=\frac{\text { Number of eggs sett- Number of clear eggs }}{\text { Number of eggs sett }} \quad X 100 \%
$$

\section{Embryo mortality}

Observation of the development of this embryo using light emitted on the surface of the egg. Mortality was measured by splitting unhatched eggs and recording the number of embryos that died.

Embryo Mortality (\%) =

$\underline{\text { (Number of fertile eggs- Number of unhatched eggs) }}$ X 100\%

\section{Hatchability}

Hatchability is the result of fertile eggs until they can hatch and are counted at the end of hatching. The hatchability can be calculated as follows. Percentage of hatchability was calculated based on fertile eggs.

$$
\text { Hatchability }(\%)=\frac{\text { Number of Eggs that hatch }}{\text { Number of fertile eggs }} \times 100 \%
$$

\section{Body weight of DOC}

Hatch weight is the weight of newly hatched chicks. Hatch weight was measured by weighing the newly hatched chicks.

\section{Experimental design}

The data obtained were recorded and tabulated and statistically analyzed using ANOVA with a factorial Completely Randomized Design (CRD) with a 2x4 treatment pattern and each treatment using 5 eggs. The first factor was the ME level (2700 and $2800 \mathrm{kcal} / \mathrm{kg}$ ) (E) and the second factor was the dose of vitamin Eselenium supplementation $(0,25,50,75$ and $100 \mathrm{ppm})$ (V). The dose of selenium is $1 \mathrm{ppm} / \mathrm{mg}$ vitamin $\mathrm{E}$. Statistical analysis is continued with Duncan's test if the results obtained provide significant or very significant differences in influence.

$$
\text { Yijk }=\mu+\alpha_{i}+\beta_{j}+(\alpha \beta)_{i j}+\varepsilon_{i j k}
$$

Where, $Y_{i j k}$ The results of the observations for the $i^{\text {th }}$ level of factor $B, j^{\text {th }}$ level of factor $B$, on the $k^{\text {th }}$ test; $\alpha_{i}=$ General average Effect of factor $A$ at level I; $\beta_{j}=$ Effect of factor $\mathrm{B}$ on the $\mathrm{j}$ level; $(\alpha \beta)_{\mathrm{ij}}=$ Interaction between $\mathrm{A}$ and $B$ at factor $A$ level $i$, factor $B$ level $j ; \varepsilon_{i j k}=$ Experimental error for $i^{\text {th }}$ level factor $A, j^{\text {th }}$ level factor $\mathrm{B}$ in the $\mathrm{k}^{\text {th }}$ replication/group.

\section{RESULTS AND DISCUSSION}

Based on the research that has been done, it was found that the effect of metabolic energy level and dose of vitamin E-selenium supplementation in the feed on the reproductive performance of Joper breeders is presented in Table 3 below.

\section{Egg weight}

Egg size selection is a selection method that aims to evaluate the feasibility of eggs to be hatched. In this study, interaction between metabolic energy levels with vitamin E-selenium and single factor vitamin Eselenium gave no significant effect $(\mathrm{p}>0.05)$ on egg weight. The single factor of metabolic energy level had a very significant effect $(p<0.01)$ on egg weight. The weight of the eggs before being put into the incubator was $61.13-65.75 \mathrm{~g}$. The egg weight obtained in this study is in accordance with the research of Rahman et al. (2016) of 60.95-61.78g and higher than Pagala et al (2020) who got an EW of 56.87g in crosses of bangkok males with laying hens and $47.09 \mathrm{~g}$ in crosses of broiler breeds with bangkok laying hens. Egg weight based on statistical analysis is known to be influenced by a single factor of ME or vitamin E-selenium supplementation. Statistical analysis showed ME had a more dominant effect on EW than vitamin E-selenium supplementation. The highest EW was obtained from treatment with a $\mathrm{ME}$ of $2800 \mathrm{kcal} / \mathrm{kg}$ and vitamin E-selenium supplementation at a dose of $100 \mathrm{ppm}$.

Factors that affect EW are the age of laying hens. environmental temperature. strain. feed and body weight. Feed plays an important role in egg production (Pagala et al. 2020). ME factor is the dominant influence on EW. this is because about $99 \%$ of the total egg lipid is in the yolk. These lipids are used to supply energy for the developing embryo. The lipid in egg yolk is not free but is in the form of lipoproteins and is derived from the synthesis of ME in feed (Nasr 2015; Liu et al. 2020). Although vitamin E-selenium supplementation did not have a dominant effect on EW. it also had an effect on increasing EW. Slozhenkina et al. (2020) reported that lipids in egg yolk are composed of phospholipids with unsaturated fatty acids that are easily oxidized. Vitamin E-selenium supplementation in this case serves to maintain the integrity of the egg yolk so that it is not damaged by ROS.

\section{Egg shell (weight and thickness)}

Interaction between metabolic energy level and single factor energy level and dose of vitamin Eselenium supplementation had no significant effect 
Table 3. The average reproductive performance of the Joper broodstock

\begin{tabular}{lccccccc}
\hline & \multicolumn{7}{c}{ Variable } \\
\cline { 2 - 8 } Treatment & $\begin{array}{c}\text { Egg weight } \\
(\mathrm{g})\end{array}$ & $\begin{array}{c}\text { Egg shell } \\
\text { weight } \\
(\mathrm{g})\end{array}$ & $\begin{array}{c}\text { Egg shell } \\
\text { thickness } \\
(\mathrm{mm})\end{array}$ & Fertility $(\%)$ & $\begin{array}{c}\text { Embryo } \\
\text { mortality } \\
(\%)\end{array}$ & $\begin{array}{c}\text { Hatchability } \\
(\%)\end{array}$ & $\begin{array}{c}\text { DOC weight } \\
(\mathrm{g})\end{array}$ \\
\hline Metabolic energy level & & & & & & \\
\hline E1 & $62.22 \pm 0.05^{\mathrm{a}}$ & $8.23 \pm 0.08$ & $0.08 \pm 0.000$ & $90.50 \pm 0.58$ & $27.22 \pm 0.76^{\mathrm{b}}$ & $72.78 \pm 0.76^{\mathrm{a}}$ & $42.53 \pm 0.19^{\mathrm{a}}$ \\
E2 & $64.01 \pm 0.02^{\mathrm{b}}$ & $8.33 \pm 0.06$ & $0.08 \pm 0.001$ & $95.00 \pm 0.71$ & $21.28 \pm 0.69^{\mathrm{a}}$ & $78.73 \pm 0.69^{\mathrm{b}}$ & $44.20 \pm 0.37^{\mathrm{b}}$ \\
\hline Suplementasion vitamin E-selenium & & & & & \\
\hline V0 & $62.77 \pm 0.52$ & $8.19 \pm 0.16$ & $0.08 \pm 0.001$ & $92.50 \pm 2.50$ & $29.19 \pm 2.71^{\mathrm{b}}$ & $70.81 \pm 2.71^{\mathrm{a}}$ & $41.50 \pm 0.42^{\mathrm{a}}$ \\
V1 & $63.20 \pm 0.48$ & $7.88 \pm 0.13$ & $0.08 \pm 0.001$ & $92.50 \pm 0.00$ & $24.81 \pm 1.00^{\mathrm{a}}$ & $75.19 \pm 0.00^{\mathrm{a}}$ & $42.50 \pm 0.17^{\mathrm{a}}$ \\
V2 & $63.10 \pm 0.41$ & $8.31 \pm 0.09$ & $0.08 \pm 0.00$ & $93.75 \pm 3.13$ & $25.28 \pm 0.14^{\mathrm{ab}}$ & $74.72 \pm 0.14^{\mathrm{a}}$ & $43.75 \pm 0.33^{\mathrm{b}}$ \\
V3 & $63.23 \pm 0.43$ & $8.63 \pm 0.13$ & $0.08 \pm 0.00$ & $92.50 \pm 1.25$ & $21.49 \pm 1.13^{\mathrm{a}}$ & $78.51 \pm 1.13^{\mathrm{ab}}$ & $44.00 \pm 0.46^{\mathrm{bc}}$ \\
V4 & $63.25 \pm 0.40$ & $8.38 \pm 0.19$ & $0.08 \pm 0.00$ & $92.50 \pm 1.25$ & $20.46 \pm 2.45^{\mathrm{a}}$ & $79.54 \pm 2.45^{\mathrm{b}}$ & $45.08 \pm 1.04^{\mathrm{c}}$
\end{tabular}

Interaction of vitamin E-selenium supplementation and metabolic energy

\begin{tabular}{llllllll}
\hline V1V0 & $61.74 \pm 0.38$ & $7.88 \pm 0.65$ & $0.08 \pm 0.00$ & $87.50 \pm 8.29$ & $34.61 \pm 6.53$ & $65.39 \pm 6.53$ & $40.67 \pm 0.41^{\mathrm{a}}$ \\
V1V1 & $62.25 \pm 0.37$ & $7.63 \pm 0.41$ & $0.08 \pm 0.01$ & $92.50 \pm 8.29$ & $26.81 \pm 3.34$ & $73.19 \pm 3.34$ & $42.83 \pm 0.50^{\mathrm{ab}}$ \\
E1V2 & $62.28 \pm 0.36$ & $8.50 \pm 0.35$ & $0.08 \pm 0.01$ & $87.50 \pm 8.29$ & $25.56 \pm 2.81$ & $74.44 \pm 2.81$ & $43.08 \pm 0.64^{\mathrm{b}}$ \\
E1V3 & $62.36 \pm 0.34$ & $8.38 \pm 0.41$ & $0.08 \pm 0.00$ & $95.00 \pm 8.66$ & $23.75 \pm 4.15$ & $76.25 \pm 4.15$ & $43.08 \pm 0.83^{\mathrm{b}}$ \\
E1V4 & $62.45 \pm 0.34$ & $8.75 \pm 0.25$ & $0.08 \pm 0.00$ & $90.00 \pm 7.07$ & $25.36 \pm 2.86$ & $74.64 \pm 2.86$ & $43.00 \pm 0.41^{\mathrm{b}}$ \\
E2V0 & $63.81 \pm 0.39$ & $8.50 \pm 0.50$ & $0.08 \pm 0.01$ & $97.50 \pm 4.33$ & $23.78 \pm 7.41$ & $76.22 \pm 7.41$ & $42.33 \pm 0.24^{\mathrm{a}}$ \\
E2V1 & $64.15 \pm 0.81$ & $8.13 \pm 0.82$ & $0.08 \pm 0.00$ & $92.50 \pm 8.29$ & $22.81 \pm 1.90$ & $77.19 \pm 1.90$ & $42.17 \pm 0.17^{\mathrm{a}}$ \\
E2V2 & $63.93 \pm 0.36$ & $8.13 \pm 0.22$ & $0.08 \pm 0.00$ & $100.0 \pm 0.00$ & $25.00 \pm 5.00$ & $75.00 \pm 5.00$ & $44.42 \pm 0.14^{\mathrm{bc}}$ \\
E2V3 & $64.09 \pm 0.20$ & $8.88 \pm 0.22$ & $0.08 \pm 0.00$ & $90.00 \pm 7.07$ & $19.24 \pm 3.99$ & $80.76 \pm 3.99$ & $44.92 \pm 0.28^{\mathrm{c}}$ \\
E2V4 & $64.05 \pm 0.29$ & $8.00 \pm 0.61$ & $0.08 \pm 0.00$ & & & & \\
\end{tabular}

a. b a. b. ab. c and d values within a column with a very significant effect $(\mathrm{p}<0.01)$ in reducing embryo mortality; improve hatchability and increase DOC weight. a very significant effect $(\mathrm{p}<0.01)$ in increasing DOC weight. a significant effect $(\mathrm{p}<0.05)$ in reducing embryo mortality and improving hatchability. a very significant effect $(\mathrm{p}<0.01)$ in increasing DOC weight.

$(p>0.05)$ on EST and EWS. The ESW obtained in this study was 7.63-8.88 $\mathrm{g}$ and the EST was $0.76-0.83 \mathrm{~mm}$. The results obtained are higher than some of the literature. Slozhenkina et al (2020) reported the ESW of Sakini chickens in Nigeria was $4.51 \mathrm{~g}$; Barbe et al. (2020) is $0.31-0.32 \mathrm{~mm}$ and Sapkota et al. (2020) is $0.29-0.43 \mathrm{~mm}$.

The quality of the eggshell has an important role during the incubation period. Eggshell quality is related to mineral metabolism. especially $\mathrm{Ca} 2+$. The main component of eggshell is calcium carbonate $\left(\mathrm{CaCO}_{3}\right)$ which is formed by $\mathrm{Ca}^{2+}$ and $\mathrm{HCO}_{3}$ (Darsi \& Zhaghari 2021). One of the declines in the quality of hatching eggs is influenced by the quality of the egg shell. The thin egg shell causes the eggs to be easily damaged and cannot be stored for long. Low egg shell quality is associated with a decrease in the intestinal ability to absorb calcium and an increase in egg size with increasing age of the breeder (Nasri et al. 2020). Egg shell thickness is influenced by heredity and mineral metabolism in the body. Shell thickness is related to calcium metabolism obtained from bone deposits and feed (Sapkota et al. 2020).

\section{Fertility}

Fertility is the ability of the breeder to produce day old chick (DOC). Interaction between metabolic energy level and single factor energy level and dose of vitamin E-selenium supplementation had no significant effect $(p>0.05)$ on fertility. The fertility obtained in this study ranged from $87.50-100 \%$. The fertility obtained is similar to Saleh et al (2019) of $73.09-90.22 \%$ and was higher than the study of Pagala et al. (2020) of 66.67$67.67 \%$. Fertility is one of the parameters to measure the success of insemination. The quality of spermatozoa has a major influence on the success of insemination (Pagala et al. 2020; Tesfay et al. 2020). In general. the 
fertility rate is influenced by the ratio of males and females. type of insemination. handling of hatching eggs. environment (Adu-Aboagye et al 2020). abnormal spermatozoa and dead spermatozoa. Good quality spermatozoa if spermatozoa abnormality $<17 \%$ and dead spermatozoa $<10 \%$ (Feyisa et al. 2018)

Spermatozoa concentration plays an important role in the success of artificial insemination. In this study, the concentration of spermatozoa used for each treatment was the same, namely 100 million spermatozoa/hens. The same thing was also reported by Saleh et al. (2019) in their research which stated that different concentrations of spermatozoa resulted in different fertility where the best fertility was obtained by artificial insemination using semen with a spermatozoa concentration of 100 million spermatozoa/hens.

Therefore. the selection of males is very important for the hatchery industry. Male selection is done by evaluating the quality of semen to determine its reproductive ability. Evaluation of semen quality and its ability to fertilize can be done by analyzing the percentage of live/dead sperm and morphological evaluation (Tesfay et al. 2020). Spermatozoa quality is influenced by several factors including age of the male, maturity, nutritional adequacy and health status of the male. Spermatozoa concentration that is too high or low actually causes a decrease in fertility.

\section{Embryo mortality}

The interaction between vitamin E-selenium supplementation and ME had no effect $(p>0.05)$ on embryonic death. Embryo mortality is more influenced by a single factor. ME factors and vitamin E-selenium supplementation factors both have an influence on embryonic death. ME plays more dominant role in reducing embryo mortality than vitamin E-selenium supplementation.

Energy has a dominant role in embryo mortality because ME has an important role in the process of egg yolk formation and egg weight. Egg yolk is a source of nutrition for embryonic development. $75 \%$ of the nutrients in egg yolk are lipoproteins (Nasr 2015; Liu et al. 2020). About $99 \%$ of the total egg lipid is in the yolk. The lipids in egg yolk are composed of phospholipids with unsaturated fatty acids that are easily oxidized (Slozhenkina et al. 2020). In breeders. surplus energy in the body is stored as body fat mass as a precursor in the synthesis of lipoproteins in egg yolk. The ME also plays a role in the absorption of vitamin E-selenium in the body (Heijmans et al. 2021; Ren et al. 2021). Vitamin $E$ is a natural antioxidant to reduce ROS in egg yolk by reducing lipid peROSidation and oxidation. Oxidation in egg yolks during the hatching process causes the production of toxic malondialdehyde which can cause embryo death. so vitamin E-selenium supplementation is effective for reducing lipid peROSidation and increasing antioxidant capacity in egg yolks which has an impact on increasing hatchability (Barbe et al. 2020).

Embryo mortality is not only influenced by the quality of the hatching eggs but also by the temperature setting in the incubator. The temperature of the incubator is very influential on the mortality of the embryo. Embryo mortality increases when the incubator temperature exceeds the optimal temperature for embryonic development. This is because the embryonic membrane becomes dry so that the embryo will experience nerve. heart. respiratory and kidney disorders (Pagala et al. 2020).

\section{Hatchability}

The interaction between metabolic energy level and the dose of vitamin E-selenium supplementation had no significant effect $(p>0.05)$ on hatchability. while the single factor of metabolic energy level had a very significant effect $(\mathrm{p}<0.01)$ on hatching weight and the single factor of supplementation dose had a significant effect $(p<0.05)$ on hatchability. The interaction between metabolic energy level and the dose of vitamin Eselenium supplementation had no significant effect $(p>0.05)$ on hatchability. While the single factor of metabolic energy level had a very significant effect $(p<0.01)$ on hatching weight and the single factor of supplementation dose had a significant effect $(\mathrm{p}<0.05)$ on hatchability. Hatchability obtained in this study ranged from $65.39-84.44 \%$ almost the same as (Pagala et al. 2020) of $85-93 \%$. Hatchability percentage is affected by a single factor of metabolic energy and vitamin E-selenium supplementation. ME more dominant influence on hatchability improvement compared to vitamin E-selenium supplementation. The increase in ME affects the higher hatchability. Nutrient requirements for embryonic development during incubation are stored in albumen. egg yolk and egg shell. The main source of energy for the development of the embryo is obtained from the yolk sac. The energy in egg yolk for embryo development is obtained from the oxidation of fatty acids in egg yolk. Fatty acid oxidation in egg yolk supplies almost $94 \%$ of the total energy requirement of the embryo during development (Nasri et al. 2020).

Slozhenkina et al. (2020) reported that the use of antioxidants in broodstock could increase hatchability. The addition of antioxidants can increase hatchability up to $14.60 \%$. The use of antioxidants will help the metabolism to be normal. Agreeing with this. Barbe et al. (2020) stated that vitamin $\mathrm{E}$ is a natural antioxidant to reduce ROS in egg yolk by reducing lipid peROSidation and oxidation. Oxidation in egg yolks 
during the hatching process causes the production of toxic malondialdehyde which can cause embryo death. so vitamin E-selenium supplementation is effective for reducing lipid peROSidation and increasing antioxidant capacity in egg yolks which has an impact on increasing hatchability (Barbe et al. 2020).

Adu-Aboagye et al. (2020) and Pagala et al. (2020) explain that there are 3 main factors that affect the percentage of hatchability. The first factor is the quality of hatching eggs. This egg quality includes egg size. egg shape. egg weight and nutrient content. Hatching eggs with low nutrient content will produce a low percentage of hatchability. Nutrients present in eggs are the main source of nutrition for embryonic development. The second factor is the handling of hatching eggs before they are put into the incubator. Handling hatching eggs includes the cleanliness of eggs and the length of storage of hatching eggs before incubation. Eggs that are dirty and stored for a long time will result in low hatchability. The third factor is the hatching process. The hatching process is concerned with setting the incubator during incubation. Setting the temperature. humidity and frequency of egg turning has an important role in determining the success of hatching.

\section{DOC weight}

Interaction between vitamin E-selenium supplementation and ME had a very significant effect $(p<0.01)$ on DOC weight. Increasing doses of vitamin E-selenium supplementation and ME had an impact on increasing DOC weight. In this study. the weight of DOC ranged from 40.67-47.17g. The quality of hatching eggs has a major role in the weight of the DOC produced. DOC weight is related to metabolic activity during embryonic development. Availability of nutrients for embryonic development is a key factor in DOC weight. Egg yolk is the main source of energy for embryo development. according to Slozhenkina et al (2020) 99\% of the constituents of egg yolk are lipids and lipid oxidation in egg yolk is used to supply energy needs for embryonic development. Hadinia et al. (2019) reported that energy intake in the body of the breeder is metabolized for maintenance. growth. and egg production. Surplus energy is stored as body fat mass. Body fat mass plays a role in egg yolk synthesis.

The metabolic activity of the embryo during incubation has an effect on the rate of embryo development. The increased energy requirements during incubation for embryonic development affect metabolism. especially oxidation reactions. Fatty acid oxidation increases with increasing energy requirements. Increased ROS in egg yolk due to high oxidation causes a low metabolic rate. Nasri et al. (2020) explained that the decrease in metabolism during incubation caused organ development and embryonic growth to not be optimal. This can cause the resulting DOC weight to be low. Supplementation of vitamin Eselenium in broodstock feed will increase antioxidant levels in hatching eggs. Barbe et al. (2020) reported that antioxidants in egg yolk will control oxidation by reducing or inactivating ROS before working on embryonic tissue.

\section{CONCLUSION}

The conclusion of this study is the interaction between vitamin E-selenium supplementation and energy levels can increase the weight of Joper's DOC, while the single factor of vitamin E-selenium supplementation and energy levels can reduce embryo mortality and increase hatchability. The best interaction with $100 \mathrm{ppm}$ vitamin E-selenium supplementation and energy $2800 \mathrm{kcal} / \mathrm{kg}$.

\section{ACKNOWLEDGEMENT}

First of all. I thank Allah for His great love for me. giving me patience and strength to complete my doctoral studies. Second. I thank the Ministry of Education and Culture for the BPPDN scholarship for funding my doctoral studies. Third. I am very grateful to my supervisor Dr. Eko Widodo for all his knowledge. advice and evaluation on my paper.

\section{REFERENCES}

Abd El-Hack ME, Mahrose K, Arif M, Chaudhry MT, Saadeldin IM, Saeed M, Soomro RN, Abbasi IHR, Rehman ZU. 2017. Alleviating the environmental heat burden on laying hens by feeding on diets enriched with certain antioxidants (vitamin $\mathrm{E}$ and selenium) individually or combined. Environ Sci Pollut Res. 24:10708-10717. DOI: 10.1007/s11356-017-8690-5.

Adu-Aboagye G, Nyameasem JK, Ahiagbe KMJ, Ansah KO, Zagbede GA, Agbe KK. 2020. Reproductive traits of the indigenous Guinea fowl under tropical humid conditions; the effect of egg size. Livest Res Rural Dev. 32 .

Amevor FK, Cui Z, Du X, Ning Z, Shu G, Jin N, Deng X, Tian Y, Zhang Z, Kang X, et al. 2021. Combination of quercetin and vitamin $\mathrm{E}$ supplementation promotes yolk precursor synthesis and follicle development in aging breeder hens via liver-blood-ovary signal axis. Animals. 11:1915.

Barbe A, Mellouk N, Ramé C, Grandhaye J, Anger K, Chahnamian M, Ganier P, Brionne A, Riva A, Froment P, Dupont J. 2020. A grape seed extract maternal dietary supplementation improves egg quality and reduces ovarian steroidogenesis without affecting fertility 
parameters in reproductive hens.Loor JJ, editor. PLoS One. 15:e0233169. DOI: 10.1371/journal.pone.0233169.

Çelebi Ş. 2019. Effect of Dietary Vitamin E, Selenium and Their Combination on Concentration of Selenium, MDA, and Antioxidant Enzyme Activities in Some Tissues of Laying Hens. Pak J Zool. 51:1155-1161.

Darsi E, Zhaghari M. 2021. Effects of Bacillus subtilis PB6 supplementation on productive performance, egg quality and hatchability in broiler breeder hens under commercial farm condition. J Appl Anim Res. 49:109117. DOI: 10.1080/09712119.2021.1893738.

Feyisa SG, Park YH, Kim YM, Lee BR, Jung KM, Choi SB, Cho CY, Han JY. 2018. Morphological defects of sperm and their association with motility, fertility, and hatchability in four Korean native chicken breeds. Asian-Australasian J Anim Sci. 31:1160-1168. DOI: 10.5713/ajas.17.0626.

Hadinia SH, Carneiro PRO, Korver DR, Zuidhof MJ. 2019. Energy partitioning by broiler breeder hens in conventional daily-restricted feeding and precision feeding systems. Poult Sci. 98:6721-6732.

Heijmans J, Duijster M, Gerrits WJJ, Kemp B, Kwakkel RP, van den Brand H. 2021. Impact of growth curve and dietary energy-to-protein ratio on productive performance of broiler breeders. Poult Sci. 100:101131.

Immawan T, Puruhita A, Cahyo WN. 2019. Risk analysis of supply chain cultivation of Joper. In: IOP Conf Ser Mater Sci Eng. DOI: 10.1088/1757899X/598/1/012015.

Liu M, Lu Y, Gao P, Xie X, Li D, Yu D, Yu M. 2020. Effect of curcumin on laying performance, egg quality, endocrine hormones, and immune activity in heatstressed hens. Poult Sci. 99:2196-2202.

Muharlien, Nursita IW, Pangestu VM. 2020. The effect of feed protein level on feed consumption, body weight gain and feed conversion of finisher Java Super male chicken. IOP Conf Ser Earth Environ Sci. 478:012044. DOI: $10.1088 / 1755-1315 / 478 / 1 / 012044$

Nasr J. 2015. Evaluation of diet formulation based on digestible amino acids and true metabolizable energy on broiler breeder performance. Cuba J Agric Sci. 49:5357.

Nasri H, van den Brand H, Najjar T, Bouzouaia M. 2020. Egg storage and breeder age impact on egg quality and embryo development. J Anim Physiol Anim Nutr (Berl). 104:257-268. DOI: 10.1111/jpn.13240.

Pagala MA, Indi A, Badaruddin R, Sandiah N, Aprianti N. 2020. The egg fertility from offspring of crossbreeding results of Bangkok chickens and laying hens. IOP Conf Ser Earth Environ Sci. 465:012052. DOI: 10.1088/1755-1315/465/1/012052.

Rahardja DP, Hakim MR, Empra T, Sahrul, Savitri RD. 2020. Effects of weight and storage duration of hatching eggs of Indonesian Local Chicken on several measures of internal quality and hatchability. IOP Conf Ser Earth Environ Sci. 492:012034. DOI: 10.1088/17551315/492/1/012034.

Rahman MK, KMajumder MK, Ali MY, Khatun MM, Kabir SE, Sakib MN, Islam MS, Akter MS, Sultana F, Ali MY. 2016. Antibiotic use to the production performance of ISA brown layer. Asian J Med Biol Res. 2:541-546.

Ren J, Tian W, Jiang K, Wang Z, Wang D, Li Z, Yan F, Wang Y, Tian Y, Ou K, et al. 2021. Global investigation of estrogen-responsive genes regulating lipid metabolism in the liver of laying hens. BMC Genomics. 22:428. DOI: 10.1186/s12864-021-07679-y.

Saleh DM, Mugiyono S, Sumaryadi MY, Nugroho AP. 2019. The effects of sperm number and insemination interval on the fertility and hatchability of Sentul hens. IOP Conf Ser Earth Environ Sci. 372:012037. DOI: 10.1088/1755-1315/372/1/012037.

Sapkota S, Kolakshyapati M, Devkota N, Gorkhali N, Bhattarai N. 2020. Evaluation of external and internal egg quality traits of indigenous sakini chicken in different generations of selection International. J Agric For. 10:41-48.

Slozhenkina MI, Struk EA, Ostrenko KC, Ovcharova AN, Yurina NA. 2020. The influence of water-soluble antioxidant on the productivity of chickens and hatching quality of eggs. IOP Conf Ser Earth Environ Sci. 548:082036. DOI: 10.1088/1755-1315/548/8/082036.

Tesfay HH, Sun Y, Li Y, Shi L, Fan J, Wang P, Zong Y, Ni A, Ma H, Mani AI, Chen J. 2020. Comparative studies of semen quality traits and sperm kinematic parameters in relation to fertility rate between 2 genetic groups of breed lines. Poult Sci. 99:6139-6146.

Wang J, Zhang C, Zhao S, Ding X, Bai S, Zeng Q, Zhang K, Zhuo Y, Xu S, Mao X, et al. 2021. Dietary apple pectic oligosaccharide improves reproductive performance, antioxidant capacity, and ovary function of broiler breeders. Poult Sci. 100:100976.

Zuidhof MJ, Fedorak MV, Ouellette CA, Wenger II. 2017. Precision feeding: Innovative management of broiler breeder feed intake and flock uniformity. Poult Sci. 96:2254-2263. 